\title{
Multimedia and Conventional Learning in Students with Visual and Auditory Learning styles: Experiments on Learning Outcomes
}

\author{
Arsyad Abd. Gani ${ }^{1}$, Nurdin Ibrahim ${ }^{2}$, Khaerudin ${ }^{3}$ \\ ${ }^{1,2,3}$ Universitas Negeri Jakarta, Teknologi Pembelajaran Department, Indonesia
}

\begin{abstract}
This study aims to compare the learning outcomes of students in the experimental and control class with visual and auditory learning styles through the use of multimedia during learning. This research is a comparative quantitative study with the subject of the study consisting of 50 students divided equally in the two classes. Then the hypothesis test was carried out using the two-way ANOVA test. Based on the results of the study it was found that there were differences in learning outcomes of students who were taught with multimedia and those taught with conventional media both those using auditory and visual learning styles. Therefore, the changing paradigm of teaching for integrated social science teachers (history, geography, and economics) should consider the quality and quantity of multimedia, then the creativity and innovation of teachers is absolutely necessary in planning, implementing and evaluating the use of multimedia in learning.
\end{abstract}

Keywords: Multimedia, Visual and Auditory Learning, Learning Outcomes

\section{Introduction}

A professional teacher is required to have various competencies, one of which is the initiator of change in the community, required to master the pedagogical, personality, social and professional competencies obtained through professional education. Therefore, a teacher must try to assume great responsibility for learning especially for students in order to improve their knowledge and results of their learning experiences. The teacher as a learning agent does not only serve as a teacher and educator, but must also have the ability to choose various learning resources that are the most accommodating and conducive for students, so students can develop their potential effectively and efficiently (Richard \& Gavriel, 2011).

In essence the learning process is a communication process that must be created or realized through delivery activities and exchanging messages or information by each teaching staff with students (Mary et al, 2014). Message or information can be in the form of knowledge, skills, ideas, experiences, and so on. In order to avoid misguidance or ambiguity in the communication process it is necessary to use facilities that help the communication process called the media. In the teaching and learning process, the media used to facilitate teaching and learning communication is called learning media.

Many studies have been conducted related to the use of learning media in encouraging effective learning processes. Lynn (2013), which examines the role of media in supporting classroom learning in today's digital world. There are several researchers concluded that the use of online media is important for teacher self-development so that it has the potential to help teachers plan, implement and evaluate learning better. Foulger et al (2013), invites teachers to use social media in the learning process. Hicks et al (2013), also initiated writing learning with digital storytelling. Cho et al (2013), also examined the role of twitter. That now there is great hope that twitter and similar technology will support the growth of teacher professionalism by allowing it to collaborate and support each other online. Teachers can exchange information, claims, theories and practices as well as teaching materials that support their professional assignments in the 
classroom (Kuzu, 2008; Cho et al, 2013; Ibrahim, 2017).

In addition, Lim et al (2013) and Yousif \& Mohammed (2018), argues that adaptation to the application of technology in learning is influenced and inhibited by various factors such as conditions related to school technology resources, school culture, readiness and the experience of teachers and students in using technology (readiness and experiences of students regarding using technology), and dynamics of social interaction in schooling systems (and the dynamics of social interactions in the school system).

Teachers in Mataram city in fact often find it difficult to choose and use learning media, the most appropriate methods and strategies for discussing one learning material, or the most preferred method for most students, so learning that is active, innovative, creative, educative, fun, happy and weighty. One study on the use of media in 100 teachers of social science conducted in Mataram city concluded five main things, namely: (1) $55 \%$ of teachers used the media in learning social sciences, (2) $23 \%$ of teachers had created their own learning media (teachers made media); (3) $97 \%$ of teachers use teaching aids that are available at school (readymade media); (4) $12 \%$ of teachers use video and television media (audio-visual media); and (5) $9 \%$ of teachers use media computers and LCD projectors (Sanisah, 2013).

In connection with the results of these studies, the results of observations of researchers in several junior high schools in Mataram city that in social science subjects, teachers often face various obstacles in delivering learning material, especially in choosing the media used. Moreover, social science subjects in junior high school are non-exact subjects delivered in an integrated manner consisting of material history, geography and economics. The field of social science by most teachers is considered (1) quite complex and requires a comprehensive understanding of all subsubjects; (2) the breadth and variety, (3) requires hard work by using interesting media so that learning is not boring. So that one way to overcome these problems is by using electronic media (video / multimedia). Indeed, teachers should innovate in their learning activities so that they can increase students' interest and learning outcomes in understanding the social sciences.

\section{Methods \\ Research Design}

This research is quantitative comparative with quasi experimental method and uses treatment factorial 2 $\mathrm{x} 2$ design. The purpose of the research is to find out the differences in student learning outcomes about integrated social sciences that are taught multimedia with those taught with conventional media in terms of student learning styles, namely auditory and visual. This research conducts quasi-experiments in the class that are available as they are, without making changes to the classroom situation and learning schedule. The treatment was carried out on integrated social science learning using multimedia media in the experimental class compared to the use of conventional media in the control class. The factorial $2 \times 2$ treatment design used in this study can be visualized in Table 1 below:

Table 1: Research Design

\begin{tabular}{|l|l|l|}
\hline \multirow{2}{*}{$\begin{array}{l}\text { Learning } \\
\text { Style }(\mathrm{B})\end{array}$} & \multicolumn{2}{|l|}{ Learning media $(\mathrm{A})$} \\
\cline { 2 - 3 } & Multimedia $\left(\mathrm{A}_{1}\right)$ & $\begin{array}{l}\text { Conventional } \\
\text { media }\left(\mathrm{A}_{2}\right)\end{array}$ \\
\hline Visual $\left(\mathrm{B}_{1}\right)$ & $\mathrm{A}_{1} \mathrm{~B}_{1}$ & $\mathrm{~A}_{2} \mathrm{~B}_{1}$ \\
& {$[\mathrm{X}, \mathrm{Y}]_{11 \mathrm{k}}$} & {$[\mathrm{X}, \mathrm{Y}]_{21 \mathrm{k}}$} \\
& $\mathrm{k}=1,2 \ldots \ldots . \mathrm{n} 11$ & $\mathrm{k}=1,2 \ldots \ldots \mathrm{n} 21$ \\
\hline Auditory & $\mathrm{A}_{1} \mathrm{~B}_{2}$ & $\mathrm{~A}_{2} \mathrm{~B}_{2}$ \\
$\left(\mathrm{~B}_{2}\right)$ & {$[\mathrm{X}, \mathrm{Y}]_{12 \mathrm{k}}$} & {$[\mathrm{X}, \mathrm{Y}]_{22 \mathrm{k}}$} \\
& $\mathrm{k}=1,2 \ldots \ldots . \mathrm{n} 12$ & $\mathrm{k}=1,2 \ldots \ldots . \mathrm{n} 22$ \\
\hline
\end{tabular}

\section{Participants}

This research was conducted in a junior high school in the Mataram city in eighth grade with a total sample of 50 students consisting of 25 students in the experimental class and 25 students in the control class.

\section{Procedure}

At the final stage of the research treatment, researchers conducted integrated social science learning outcomes tests on all students who were the subjects of the study on the same day, hour and duration. This is done to see the effect of the treatment of the use of multimedia and conventional learning media with the time given in answering the 
test is 40 minutes. The test results were analyzed, including descriptive and inferential data analysis.

\section{Findings}

This research is an experimental research by testing hypotheses using $2 \times 2$ factorial analysis techniques which are used to test hypotheses about the average differences between sample groups. The testing criteria influence the average by comparing $\mathrm{F}_{\text {count }}$

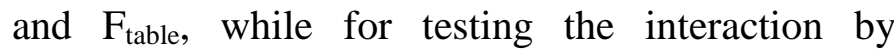
developing $\mathrm{F}_{\mathrm{AB}}$ and $\mathrm{F}_{\text {table. The hypothesis testing }}$ procedure in this study uses Analysis of Two-Way Variance (ANAVA) with the same cell. Based on these criteria, the results of the treatment are obtained according to Table 2 and Table 3 below.

Table 2: Average Score Between Experimental Classes

\begin{tabular}{|l|l|l|}
\hline $\begin{array}{l}\text { Learning style } \\
(\mathrm{B})\end{array}$ & \multicolumn{2}{|l|}{ Learning media $(\mathrm{A})$} \\
\hline & Multimedia $\left(\mathrm{A}_{1}\right)$ & $\begin{array}{l}\text { Conventional } \\
\text { media }\left(\mathrm{A}_{2}\right)\end{array}$ \\
\hline Visual $\left(\mathrm{B}_{1}\right)$ & 38.85 & 33.86 \\
\hline Auditory $\left(\mathrm{B}_{2}\right)$ & 32.50 & 42.45 \\
\hline
\end{tabular}

Table 3: Average Score Between Experimental Classes

\begin{tabular}{|l|l|l|l|}
\hline Source & $\mathrm{F}_{\text {count }}$ & $\mathrm{F}_{\text {table }}$ & Decision \\
\hline $\begin{array}{l}\text { Learning media } \\
(\mathrm{A})\end{array}$ & 9.06 & 3.94 & Ho rejected \\
\hline Learning style (B) & 13.31 & 3.94 & Ho rejected \\
\hline Interaction (AB) & 4.37 & 3.94 & Ho rejected \\
\hline
\end{tabular}

Based on Table 2 and Table 3 above and the testing criteria for the average interaction both on learning media and interaction, it can be concluded that there are differences in student learning outcomes between the two groups, in other words, students taught with multimedia learning have more height of learning outcomes of students taught with conventional learning media.

\section{Discussions}

There are differences in student learning outcomes learned with multimedia and those taught with conventional media. This is concluded based on the results of data analysis on ANAVA test which shows that $F_{\text {count }}(9.06)>F_{\text {Tabel }}$ (3.94) with 5\% free degree, and if you see the average score of student learning outcomes taught with multimedia amounted to 36.93 and average the score of student learning outcomes taught conventionally is 34.40 . This means that in general the learning outcomes of students who are taught with multimedia are better than the learning outcomes of students who are taught with conventional media. From the results of this analysis it can be concluded that the hypothesis states "Student learning outcomes about integrated social sciences that are taught with multimedia are higher than students who are taught with conventional media" proved the truth.

The use of multimedia helps students more freely to explore their abilities. This proves that multimedia is able to attract the senses and attract interest, because it is a combination of guidance, sound and movement. Teachers have more opportunities to make learning designs that are varied and certainly better than traditional learning patterns. Computer Technological Research (CTR) states that people are only able to remember $20 \%$ of those seen and $30 \%$ of those who are heard. But people can remember $50 \%$ of what is seen and heard and $80 \%$ of it is seen, heard and done all at once and not so with the conventional learning approach. Similarly Smaldino et al (2012), also presents several facts about how large the role of multimedia in supporting effective learning. In this case the teacher can do $5 \mathrm{P}$ which includes, namely preview, prepare the environment and equipment (prepare), prepare teaching material (programs), learner involvement (participation) and provide a learning experience (provide). Proponents of multimedia state that if various sensory media are combined, the effect produced exceeds the sum of the parts and is better than traditional learning. Other opinions are even more assertive that the use of multimedia in learning promises a wider impact than traditional learning as long as the multimedia used is chosen, designed and used properly and appropriately (Devon, 2010). The reason is that the use of multimedia provides an opportunity for both teachers and students to create a conducive classroom atmosphere, effective multi-purpose communication and a more interesting and lasting learning experience. Teachers will be more free to create and innovate in an effort to arouse students' enthusiasm in learning. 
The results of this study reinforce previous research conducted by Sudarti (2013), which states that there are significant differences in entrepreneurial learning outcomes between students who study using the multimedia assisted inquiry model and students who study using conventional models. In this case, there are differences in previous research with research conducted by researchers that is located on the object of subjects between entrepreneurship subjects and integrated social science subjects. However, the results of this study can strengthen the theory that the use of multimedia can improve student learning outcomes when compared to the use of conventional media.

\section{Conclusion}

This study found that there were differences in student learning outcomes learned with multimedia and those taught with conventional media, through (1) changes in the teaching paradigm for integrated social science teachers (history, geography, and economics) should consider the quality and quantity of multimedia use; (2) the side of teacher creativity and innovation is absolutely necessary in planning, implementing and evaluating the use of multimediabased learning media in learning.

Therefore, researchers give advice to social science teachers to seek the use of multimedia more intensively with various considerations, such as (1) the selection of appropriate multimedia in accordance with teaching materials, student age and other characteristics that enable students to truly focus and enjoy ongoing learning; (2) using multimedia proportionally and functionally. Media should function as a learning aid and optimal involvement of students is needed. For this reason, teachers should be able to conduct classroom management and management of learning that focuses on student activities.

\section{Acknowledgements}

Thank you to all those who have helped especially my doctoral promoter, Mr. Nurdin Ibrahim and Mr. Khaerudin. Then, thank you also to the schools that have allowed researchers to experiment, so that this research is done well. Hopefully the results of this study will be useful for the advancement of education in the future.

\section{References}

[1] Devon C., D, "Technology and the Educational Process: Transforming Classroom Activities". International Journal of Instructional Media, 27(1), pp. 67-72, 2010

[2] Foulger, S., T., et al., "License to Drive, License to Learn. Promoting Policy for Safe and Innovative Social Networking Use Schools". Spring, 6(2), pp. 97-106, 2013.

[3] Hicks, T., Turner, K., \& Stratton, J., "Reimagining a Writer's Process Through Digital Storytelling”. Spring, 6(2), pp. 167-182, 2013

[4] İbrahim, D., "Teaching Argumentation by Using Facebook Groups". International Journal of Instruction, 10(1), pp. 151-168, 2017

[5] Kuzu, A., K., "Views of Pre-service Teachers on Blog use for Instruction and Social Interaction". Turkish Online Journal of Distance Education-TOJDE, 8(3), pp. 34-51, 2008

[6] Lim, C., P., Zhao, Y., Tondeur, J., Chai, C.-S., \& Tsai, C., C., "Bridging the gap: Technology Trends and Use of Technology in Schools". Educational Technology \& Society, 16(2), pp. 59-68, 2013

[7] Lynn, B., K, "Teaching and Learning in the Digital World: Possibilities and Challenges". Spring, 6(2), pp. 1-424, 2013

[8] Mary, B., Elizabeth, P., \& Shylaja, R, "Working together: How Teachers Teach and Students Learn in Collaborative Learning Environments". International Journal of Instruction, 7(1), pp. 17-32, 2014

[9] P. S. Aithal, P. Shubhrajyotsna Aithal, "An Innovative Education Model to realize Ideal Education System", 3(3), pp. 2464-2469, 2015

[10] Richard, E., C., \& Gavriel, S, "Media in teaching. Israel: University of Southern California Press, 2011

[11] Sanisah, S, "Evaluasi Penggunaan Media Pembelajaran Pada Mata Pelajaran IPS Jenjang SMP di Kota Mataram. Journal of Education Community, 7(1), pp. 33-39, 2013

[12] Smaldino, S., E., Lowther, D., L. \& Russell, J., D. Instructional Technology \& Media for 
Learning. New York: Pearson Education, Inc, [15] Vincent, C., Jina, R., \& Josh, L., T, "What 2012. Twitter Will and Will Not Do: Theorizing about

[13] Seth Asare Danso, "Moral Education and the Teachers' Online Professional Communities". Curriculum: the Ghanaian Experience", IJSRM, 6(1), pp. 34-42, 2018 Spring, 6(2), pp. 45-60, 2013

[14] Sudarti, D, "Perbandingan Hasil Belajar [16] Vandna, Ritu Sindhu, "Application and Kewirausahaan Siswa yang Belajar Research of Multimedia Technology in Modern Menggunakan Model Inkuiri Berbantuan [17] Multimedia dengan Siswa yang Belajar Menggunakan Metode Konvensional di SMK Adipura Magelang Kelas XI'. OIKONOMIA: Jurnal Pendidikan Ekonomi, 2(3), 247-254, Teaching". IJSRM, 3(4), pp. 2632-2634, 2015 2013. Yousif, A., A., \& Mohammed, A., A. "The Impact of Using Mobile Social Network Applications On Students' Social-Life". International Journal of Instruction, 11(2), pp. 1-14, 2018. 